\title{
Med blå briller - men uden overskæg
}

Om general Ludendorffs flugt til København og Skåne i november 1918, og om Ludendorffs manuskript til Meine Kriegserinnerungen 1914-1918

"Vi lyttede forbavsede til fremstillingen, men brod ind med et inkvisitorisk:

- 'OG HVOR ER SA DET MANUSKRIPT NU, ERIK?'

- 'Ja, min fader blev rent ud forbandet på Ludendorff, efter at han var begyndt at samarbejde med Hitler, så manuskriptet blev solgt med den klausul, at det ikke måtte salges til Tyskland eller til en tysker...”"

afforskningsbibliotekar Jesper Düring Jorgensen, Det Kongelige Bibliotek

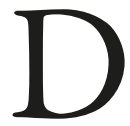
et var den 8. november 1918. Denne dags aften ankom Hauptmann Adolf Fischer til sin lejlighed i Holsteinische Strasse nr. 20 i Berlin efter en tjenesterejse til Petrograd. Adolf Fischer gjorde tjeneste i det tyske krigsministerium, men var akkrediteret gesandtskaberne i Christiania, Stockholm og København. Han var baseret i den danske hovedstad og havde ansvar for de tyske krigsfanger, der var interneret på dansk, neutral grund. Formålet med rejsen til Petrograd havde formodentlig været at føre forhandlinger om tyske soldater i russisk fangenskab, men før han kunne fortsætte mod København, måtte han aflægge referat hos sine foresatte i krigsministeriet om rejsens udfald. ${ }^{1}$

Den 9. november brød revolutionen ud i Berlin. Ved aftentide den følgende dag bad en kollega i krigsministeriet, en Hauptmann Schumacher, Fischer om at komme til adressen Güntzelstrasse 66, 1. sal. - "Man venter Dem der," lød det kryptisk. Fischers nysgerrighed blev vakt, og han henvendte sig på adressen til den aftalte tid. Her fandt han et større selskab af damer og herrer samlet, ægteparret
Schumacher, en Hauptmann Wilhelm Breucker og frue, der beboede lejligheden, samt flere andre. - Da rejste der sig en herre, som havde siddet noget tilbagetrukket fra det øvrige selskab. Han gik hen til Fischer og gav ham hånden. Ud fra de officielle billeder, som Fischer så hyppigt havde set gennem de fire år, krigen havde varet, genkendte han den fremmede herre i det civile jakkesæt som Erster Generalquartiermeister Erich Ludendorff. Den mand, der på det nærmeste havde været det kejserlige Tysklands diktator de sidste år under Den store Krig, men nu stod han her i civil ligesom det øvrige selskab. Han trak Adolf Fischer ned på en stol ved siden af sig, skænkede vin til dem begge, og påbegyndte en analyse af revolutionen, sådan som den tegnede sig for hans øjne. Generalen mente, at han nu ville blive forfulgt af spartakister og oprørske matroser, frygtede at blive hængt i den første og bedste lygtepæl, og han havde set sig nødsaget til at skifte opholdssted dag for dag. Han havde via Wilhelm Breucker rettet forespørgsel til den nye krigsminister, Generalløjtnant Heinrich Schëuch, og gennem ham til rigskansler Ebert, om 


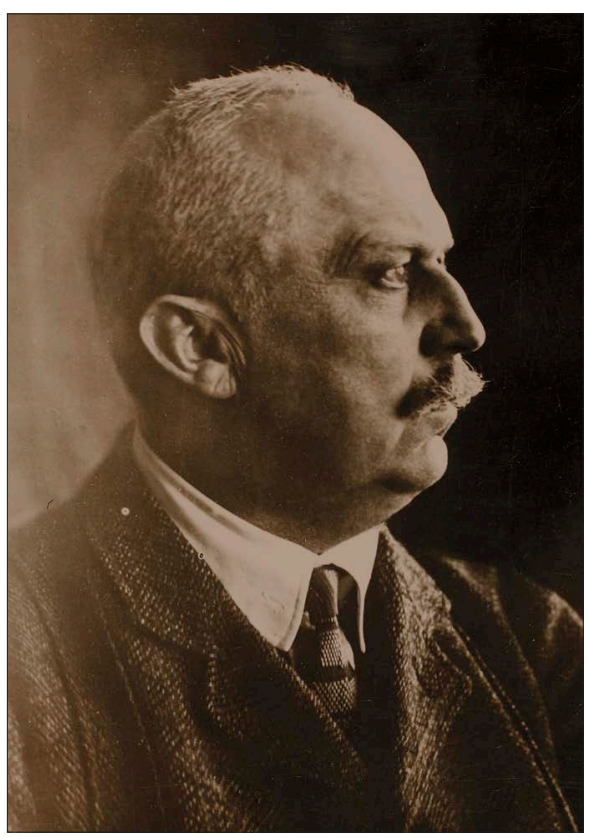

Ludendorffi civil fotograferet 1923 under processen mod kupmagerne fra "Olstuekuppet" samme air. Det Kongelige Bibliotek, Billedsamlingen.

Tysklands nye magthavere ville garantere ham hans personlige sikkerhed, et spørgsmål som krigsminister og rigskansler kun havde besvaret valent med, at det næppe ville være praktisk muligt at sørge for Ludendorffs sikkerhed. Tysklands nye regime - Rat der Volksbeauftragten - kunne eller ville intet gøre for den tidligere næsten almægtige Erster Generalquartiermeister; til gengæld udleverede Heinrich Schëuch, nogle uudfyldte, udenlandske pasformularer, idet regimet gerne så, at Ludendorff forlod Tyskland; det ville mindske de politiske spændinger i landet, hed det, og det skulle helst finde sted på et falsk pas, så generalen så vidt muligt undgik at blive opdaget ved grænsen af de oprørske arbejder- og soldaterråd, der nu førte kommandoen på gaden. En opdagelse kunne blive pinlig for regimet. Endelig skulle det falske pas sløre Ludendorffs identitet i det neutrale land, der måtte optage flygtningen, således at man der havde en chance for at undgå et muligt pres fra Ententen for at få ham udleveret, hvilket i sidste instans også kunne blive en pinlig affære for Rat der Volksbeauftragten. ${ }^{2}$ Men nu - denne aften den 10. november, ville general Ludendorff så vide, om Adolf Fischer var parat til at tage ham med til Skandinavien, måske til Danmark, og Fischer erklærede sig rede til at gøre forsøget. Som officer i den tyske hær fandt han, at det var en pligt, han ikke kunne undslå sig for, men han syntes samtidig, at eventyret $\mathrm{i}$ dette tilfælde gik hånd $\mathrm{i}$ hånd med pligten, og det gjorde udslaget. Her er det påfaldende, at Hauptmann Breucker årtier senere i sin bog Die Tragik Ludendorffs, hævder, at det var Fischer, der uopfordret tilbød at tage Ludendorff med til Danmark. ${ }^{3}$ Det kan gerne være, men Breucker havde gennem hele sin militære karriere haft et nært, beundrende forhold til Ludendorff og til- og omtalte ham som "Vater." Han kan derfor have haft en interesse $i$ at fremstille Ludendorff som manden, der ikke ville flygte og svigte sit ansvar, men som derimod havde forladt Tyskland nærmest på ønske af de nye magthavere og med løfte om at vende tilbage og stille sig til rådighed for en undersøgelseskommission.

Til gengæld kendte Adolf Fischer ikke forud noget til Ludendorffs person, og han kan næppe have været engageret personligt på samme måde som Breucker i problemet vedrørende generalens sikkerhed. På den baggrund virker det lidt usandsynligt, at Fischer uopfordret skulle have tilbudt at smugle generalen 
ud af Tyskland; desuden skal man huske på, at han angiveligt var blevet bedt om at komme til Ludendorffs opholdssted i Güntzelstrasse nr. 66, "hvor man ventede ham.” Hvis det er gået sådan til, har der på forhånd fra Breuckers og Ludendorffs side været et formål med invitationen, som Fischer næppe uden videre har kunnet gennemskue, men hans diplomatiske status i København kan derimod have gjort ham til et interessant bekendtskab for Ludendorff og hans hjælper i den betrængte situation, som generalen befandt sig i. Imod denne hypotese og Fischers fremstilling taler dog, at Hauptmann Schumacher, der havde opfordret Fischer til at komme til adressen i Güntzelstrasse, gennem sit ægteskab var knyttet familiært til Erich Ludendoff, og hvis Fischer har været bekendt med det forhold, kan det have givet ham en anelse om hensigten med invitationen; måske er han ikke blevet slet så overrasket over at antræffe Ludendorff $\mathrm{i}$ civil hos ægteparret Breucker, som han giver udtryk for i sin beretning. Herved kan det ikke udelukkes, at Wilhelm Breucker kan have ret i sin påstand om, at Fischer uopfordret skal have tilbudt at tage den forfulgte general med til Danmark, men hvad der er op og ned i denne detalje af historien, lader sig næppe endeligt opklare ud fra de givne kilder.

Det var først Adolf Fischers tanke at flyve generalen til Jylland og bringe ham til Hald ved Viborg, idet Fischer var en god bekendt af den daværende ejer, hofjægermester Aage Krabbe, men ifølge Fischer ville Ludendorff ikke risikere livet i en skrøbelig flyvemaskine og insisterede på at rejse med tog. Denne rejseform havde til konsekvens, at det blev påkrævet at udfylde de udleverede, udenlandske pasformularer og fremskaffe visum, så generalen diskret kunne forlade Tyskland inkognito. Det lykkedes Hauptmann Breucker og krigsminister Heinrich Schëuch at komme i forbindelse med den formående Legations- und Geheimrat Oskar Trautner i Auswärtiges Amt, der på sin side fik legationsråd E.F. Wrede ved den finske repræsentation i Berlin til at udstede et finsk diplomatpas, der forvandlede Erster Generalquartiermeister Erich Ludendorff til finsk kommerce- og legationsråd Ernst Lindström fra Åbo, et navn, der blev valgt, fordi initialerne E.L. var de samme som generalens. ${ }^{4}$ For yderligere at lægge afstand til sin oprindelige identitet, skjulte Ludendorff sig bag et par blå briller og havde fjernet sit karakteristiske overskæg. Samtidig trak Hauptmann Breucker og måske også Adolf Fischer i trådene i det danske gesandtskab, således at der blev udstedt et dansk visum til finsk legationsråd Ernst Lindström. En handling, som Adolf Fischer siden i sin beretning bedømte som misbrug af sin stilling; men måske har det ikke været helt så galt. I de øvrige fremstillinger, der findes om passpørgsmålet, er Adolf Fischer ikke nævnt som delagtig i processen, hvorimod Wilhelm Breucker ganske detaljeret har beskrevet initiativet som et samarbejde mellem ham og den finske diplomat E.F. Wrede, mens finsk legationssekretær A.W. Ström efter E.F. Wredes erindringer afhentede passet i det danske gesandtskab, ligesom hele intrigen fandt sted i forståelse med den finske ambassadør i Berlin, Edward Hjelt. Sidstnævnte undlod at underrette den finske udenrigsminister om den delikate sag, mens den pågik, og det falske pas kom heller ikke til at figurere på repræsentationens liste over udstedte pas. Det var i øvrigt en betingelse fra finsk side, at 
Ludendorff skulle tilintetgøre passet, når han nåede København, en betingelse, som generalen ikke overholdt. Når de finske diplomater gik aktivt ind på at skaffe Ludendorff en finsk identitet, skyldtes det, at både E.F. Wrede og Edward Hjelt følte taknemmelighed overfor Ludendorff på grund af hans støtte under befrielsen af Finland; desuden var Hjelt personligt udpræget sympatisk indstillet overfor Tyskland. Pasaffæren og Hjelts positive holdning overfor Tyskland kostede ham siden posten i Berlin, da det af hensyn til Ententen og de nye vinde, der blæste efter våbenstilstanden, blev ubekvemt for Finland at demonstrere sympatiske relationer overfor Tyskland. ${ }^{5}$

Den 15. november 1918 om formiddagen kørte Adolf Fischer og den tilsyneladende finske legationsråd uantastet gennem Berlin til Stettiner Bahnhof i den finske ambassadørs bil for at afrejse med toget til Rostock, hvor de så sig nødsaget til at overnatte. Dagen efter fortsattes turen mod København. Ved hjælp af det danske "Laissez-passer" og ved passende autoritær optræden fra Fischers side lod grænseofficeren dem passere i Warnemünde, og de nåede begge velbeholdne ombord på færgen til Gedser. Her fremdrog den forvandlede general en flaske cognac, som han en gang i bedre tider havde fået forærende af kejseren, og begge de herrer drak da en lettelsens skål i Wilhelm $2 . s$ cognac. Adolf Fischer havde håbet, at han og hans ledsager kunne forblive ubemærkede under overfarten, men håbet blev skuffet. Da legationsråden og Fischer trak frisk luft på dækket, blev Ludendorff genkendt af den tyske søofficer, Fregattenkapitän Fritz West, - tidligere chef på minekrydseren Albatross. Han var sammen med den overlevende del af sin besætning blevet interneret i Sverige i 1915 efter at have måttet sætte den ukampdygtige og synkefærdige Albatross på grund på Gotlands kyst efter minekrydserens uheldige møde med et par svære russiske krydsere. - Men denne dag, den 16. november 1918 på færgen til Gedser havde fregatkaptajnen - der åbenbart kunne færdes frit på dette tidspunkt - pludselig lagt en hånd på Fischers skulder og hvisket: "De bliver sikkert glad, når De kan lægge Deres mission bag Dem?" - "Så hold De i det mindste Deres mund," snerrede Fischer overrumplet. ${ }^{6}$ Formentlig rettede Fritz West sig efter opfordringen, selv om Fischer beretter, at det ikke var tilfældet. Det ærgrede ham i alt fald efterfølgende at konstatere, at man på gesandtskabet $\mathrm{i}$ København havde været fuldt underrettet om hans og generalens rejse, allerede før deres ankomst til den danske hoved- og residensstad. Men Fritz West er formentlig uskyldig; det forekommer langt mere sandsynligt, at Vortragender Legationsrat Oskar Trautmann i Auswärtiges Amt kan have følt en trang eller en tjenestelig forpligtelse til at underrette den tyske repræsentation i København om, hvad der var i gærde; det har han sikkert gjort pr. telegram, allerede før Fischer og hans ledsager afrejste fra Stettiner Bahnhof.

Først sent på aftenen den 16. november var Adolf Fischer og hans ledsager fremme, og Fischer fik indlogeret den forlorne, finske legationsråd på Hotel Phønix, værelse nummer 9.

Ganske tidligt den følgende morgen blev Adolf Fischer vækket i sin lejlighed i Bredgade af en herre fra gesandtskabet, der i stor ophidselse kunne oplyse, at man havde kendskab til hans bedrift. Fischer stod op, og trods det tidlige tidspunkt lod han sig melde hos den tyske gesandt 
Ulrich Graf von Brockdorff-Rantzau for at aflægge forklaring. En opdukken som på ingen måde var velkommen hos den tyske gesandt, der bl.a. havde den excentricitet hovedsagelig at arbejde om natten for så at sove uforstyrret til langt op ad dagen. Først efter lang tids påtrængende insisteren lod gesandten sig se, men allerede under Adolf Fischers første ord kastede han sig opbragt og opgivende i en lænestol. Brockdorff Rantzau mente, at hele hans politik, der gennem de fire krigsår havde gået ud på at holde Danmark klar af enhver mulig gnidning med det kejserlige Tyskland, nu var bragt i alvorlig fare med Ludendorffs ankomst til København, noget han ganske vist havde været bekendt med allerede aftenen i forvejen, og som derfor næppe kunne have overrumplet ham denne morgen, men som tydeligvis havde provokeret ham, måske også fordi han i løbet af krigsårene havde oparbejdet en personlig og stadigt voksende antipati mod den næsten almægtige Erster Generalquartiermeisters person, efterhånden som krigen skred frem. Gentagne gange for han op og nærmest skreg lige ind $i$ ansigtet på Hauptmann Fischer: "Schaffen Sie mir sofort den Mann aus dem Land!" - Skaf mig straks den mand ud af landet. - Tidligere havde Adolf Fischer ellers stået på god, fortrolig fod med gesandten, men denne samtale blev den sidste personlige imellem dem. Herefter værdigede gesandten ikke Fischer nogen opmærksomhed ud over det tjenesteligt strengt nødvendige. I sine i 1940 posthumt udgivne erindringer nævner Ludendorff, at han ved ankomsten til København havde meldt sig hos Brockdorff-Rantzau. På baggrund af Fischers fremstilling af forholdet mellem Ludendorff og gesandten, herunder

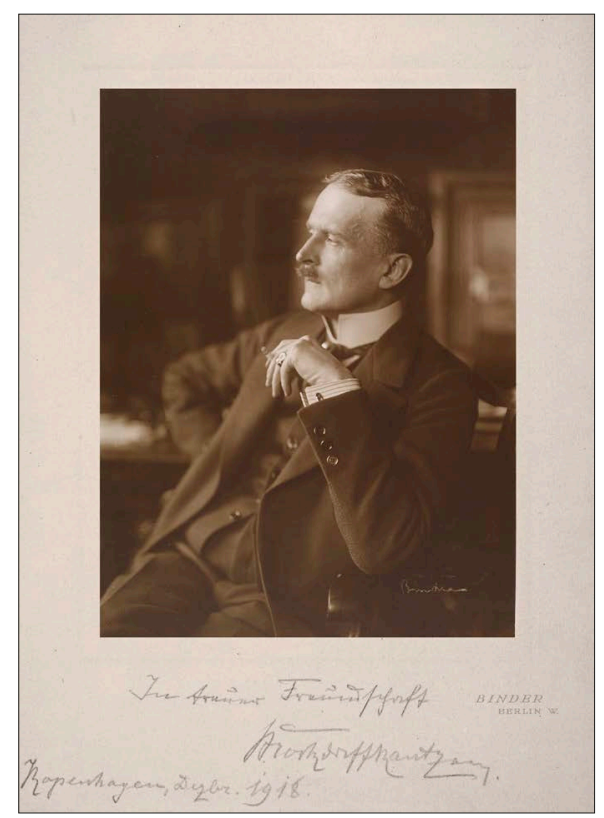

Brockdorff Rantzau med dedikation til Erik Scavenius: Im treuer Freundschaft, Brockdorff-Rantzau Kopenhagen Dezember 1918. Det Kongelige Bibliotek, Billedsamlingen.

ikke mindst Brockdoff-Rantzaus reaktion overfor Fischer virker det temmelig usandsynligt, hvilket yderligere understreges af, at Brockdorff-Rantzau i 1921 udfordrede Ludendorff til duel, efter at generalen havde anklaget ham for allerede i sin tid som gesandt i København at have arbejdet på at omstyrte kejserriget. ${ }^{7}$ Til gengæld blev det ganske hektisk for Adolf Fischer de følgende dage, hvor det gjaldt om at skaffe Ludendorff logi. I starten fulgte han åbenbart ikke gesandtens ordre om at få generalen anbragt udenfor Danmark. Et tilbud om at huse den faldne storhed fra en tidligere dansk officer, der ifølge Fischer skulle have haft et tvivlsomt ry, blev afslået, mens andre af Fischers bekendtskabskreds i Danmark forholdt sig særdeles nølende til at huse generalen. 
Efter at Fischer forgæves havde rejst kongeriget rundt i bil for at skaffe Ludendorff tag over hovedet, lykkedes det til sidst Marion von Neergaard, der var gift med den tyske marineattaché, at få Ludendorff anbragt hos svenske venner i Skåne. Herved opfyldte Adolf Fischer endelig gesandtens forlangende, idet Ludendorff den 24. november 1918 blev anbragt på herregården Hässleholmgård i Skåne hos den i Sverige kendte konkurrencerytter og hesteavler Ragnar Olsson. Det betød tillige, at der måtte skaffes Ludendorff endnu et falsk visum, denne gang et svensk, og situationen tvang samtidig Fischer til at tilstå overfor den svenske gesandt i København, baron Beck-Friis, at det ønskede visum ikke gjaldt nogen finsk legationsråd, men selveste general Ludendorff. I sin beretning fremhævede Adolf Fischer den svenske gesandt som en diplomat af den gamle skole, idet Beck-Friis havde udstedt det ønskede visum med en erklæring om, at han personligt tog ansvaret for ikke at underrette den svenske regering om legationsrådens sande identitet; og han indskrænkede sig herefter til blot at melde Utrikesdepartementet i Stockholm, at han havde viseret finsk legationsråd Ernst Lindströms pas. ${ }^{8}$ Siden, da Ludendorffs identitet og ophold i Skåne blev kendt, måtte Beck-Friis indkassere en alvorlig reprimande fra det svenske udenrigsministerium. I sin beretning nævner Fischer, at det ligefrem var på et hængende hår, at han var blevet afskediget.

Det var på høje tid at få Ludendorff ud af Danmark. På trods af tillagte blå briller og bortbarberet moustache var generalens inkognito ved at være tyndslidt. Frisøren på Hotel Phønix, der havde klippet ham dagen efter hans ankomst, havde til Fischers overraskelse meget professionelt genkendt ham ud fra hans hovedform, og på Krogs Fiskerestaurant, hvor den formentlige legationsråd havde ladet sig friste til at indtage en middag, var han blevet iagttaget med vantro bestyrtelse. I sine posthumt udgivne erindringer udtrykte Ludendorff siden tilfredshed med at forlade Danmark. Han nærede ingen tiltro til noget eksil her, idet han uden videre afgjorde, at Danmark dels var tyskfjendtlig, dels havde optrådt som ligrøver ved at kræve Nordslesvig afstået af Tyskland. ${ }^{9}$

I december 1918 fik Hauptmann Fischer endnu en diskret kommission at forrette; han måtte påtage sig at ledsage Ludendorffs hustru, Margarethe Ludendorff, til Hässleholmgård, så generalinden kunne fejre julen 1918 sammen med ægtemanden. Det blev dog en ganske besværlig opgave for Fischer, og han karakteriserede den selv som sit livs mest ubehagelige rejse, hvilket vist vil sige ganske meget $\mathrm{i}$ betragtning af de egne af verden, som Adolf Fischer tidligere havde berejst - og kæmpet i. Mellem 1904 og 1913 havde han tre gange gjort tjeneste i Tysk Sydvestafrika - det nuværende Namibia og deltaget i nedkæmpelsen af herero-oprøret mellem 1904 og 1907. Da Verdenskrigen brød ud, kunne man have ventet, at Fischer endnu en gang var blevet sendt til Afrika, men i stedet blev han forsat til Mellemøsten, hvor han gjorde tjeneste i det tyrkisk-tyske ekspeditionskorps fra den 9. september 1914 indtil den 4. oktober 1916. I 1915 og 16 havde Fischer deltaget i de såkaldte Sinaifelttog, og han nåede også at komme til Afghanistan, før han i 1917 blev overført til det tyske gesandtskab i København.

Adolf Fischers tre ophold i Namibia og hans jagtinteresse synes at have ud- 


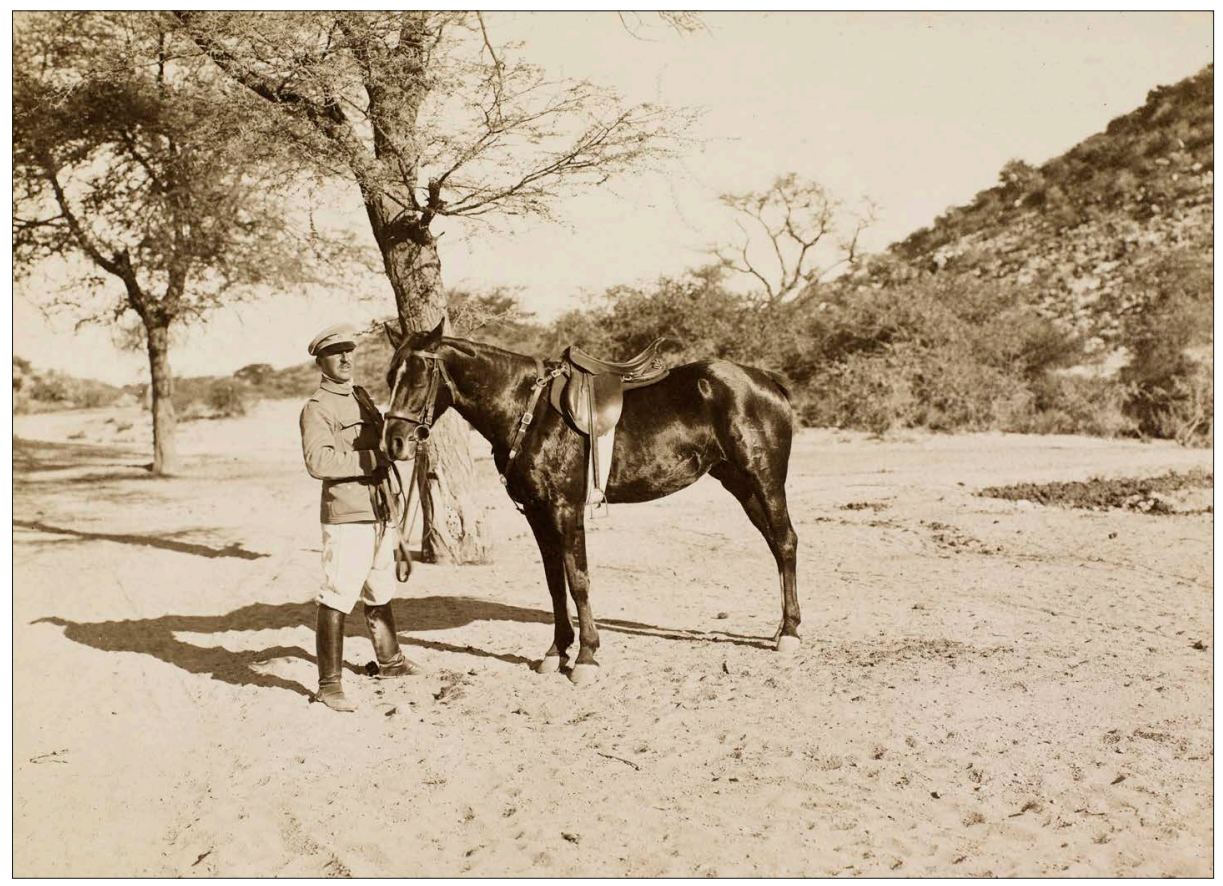

AdolfFischeri Namibia 1910 med sin hest Anton. Det Kongelige Bibliotek, Håndskriftsamlingen.

viklet sig til en dyb, passioneret interesse for landets natur, dyreverden og dets oprindelige indbyggere. Han havde haft soldatens opgave, men havde jægerens blik og endte med at betragte natur og mennesker nærmest med en antropologs øjne. ${ }^{10}$ Tiden i Namibia gjorde ham til forfatter, og i 1914 udgav han bogen Menschen und Tiere in Deutsch-Südwest. Med årene blev bogen en succes, der kom i 6 oplag, det seneste i 1936.

Adolf Fischer forlod den tyske hær efter Verdenskrigen, blev dansk gift og bosat i Danmark. Han nåede i løbet af tyverne og trediverne at skrive yderligere to bøger om Sydvestafrika og Mellemøsten samt bidrage til et samleværk om Tysk Sydvestafrika. ${ }^{11}$ Selv om Adolf Fischer genudsendte to af sine bøger og publicerede den nye, Südwester Offiziere, efter Hitlers magtovertagelse, betød det ikke, at han nærede sympati for nazismen. Under publiceringen af Südwester Offiziere i 1935 frygtede forlaget Safari Verlag ligefrem beslaglæggelse af bogen, fordi Fischer, som forlaget skrev til ham, havde udtrykt sig i direkte modstrid med den nazistiske "verdensanskuelse," og ud over strygninger forlangte forlaget vennen Maximilian von Hardens navn og hans tidsskrift die Zukunft, som Fischer havde omtalt, fjernet fra bogen. Stillet over for denne forsigtighedscensur fra forlagets side, havde Fischer været på nippet til at trække bogen tilbage, men man nåede et kompromis, som han valgte at leve med. Med den aristokratisk-heroiske holdning til tilværelsen, der kommer til udtryk i Südwester Offiziere, kunne Adolf Fischer i grunden minde noget om Vilhelm 


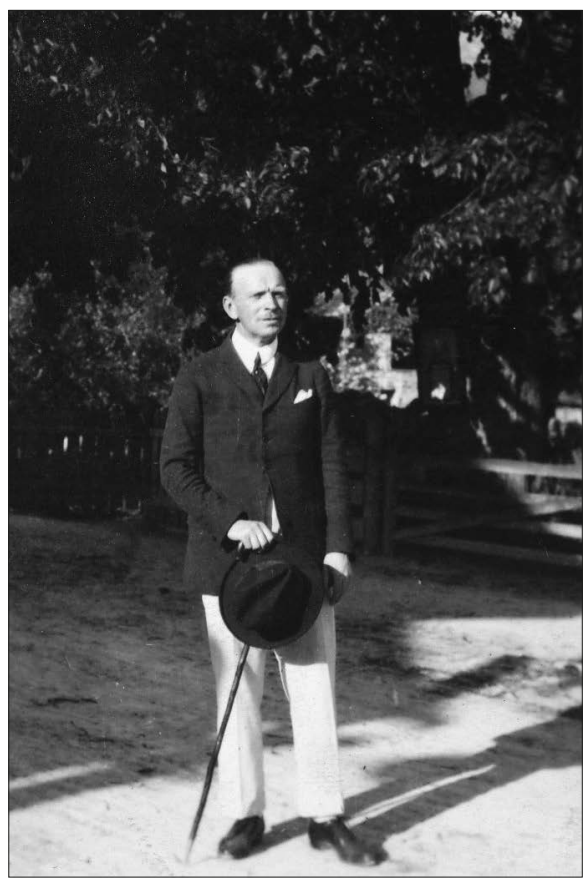

Adolf Fischer i civil ca. 1921. Det Kongelige Bibliotek, Haindskriftsamlingen.

Dinesen dog uden dennes indre uro og depressive træk. Men han var formet af en dannelse og en indstilling til tilværelsen ud af det sene 19. århundrede, der efter 1918 uhjælpeligt hørte til i "verden af $\mathrm{i}$ går.” - Det var på ingen måde nogen gennemsnitlig tysk officer, der havde påtaget sig opgaven som "sluser" for ægteparret Ludendorff.

\section{Meine Krigserinnerungen 1914-1918}

Umiddelbart efter sin ankomst til

Hässleholmgård begyndte Ludendorff udarbejdelsen af sin bog Meine Kriegserinnerungen 1914-1918. Måske gik han i gang med arbejdet allerede på aftenen for sin ankomst til København; en sådan hensigt gav han i alt fald udtryk for i et brev til sin i Berlin efterladte hustru Mar- garethe Ludendorff, men sporvognsstøjen fra Bredgade gik ham på nerverne og hindrede både arbejde og søvn. ${ }^{12}$ Når det havde en sådan hast med dette arbejde, er en forklaring, at værket ikke alene skulle være et opbyggeligt erindringsværk for den tyske nation om generalens bedrifter under Den store Krig, men i lige så høj grad fungere som en retfærdiggørelse af hans måde at føre krigen på og måske derved indirekte virke som en form for livsforsikring, hvis det skulle komme til anklager mod ham for forsyndelser mod den tyske stat eller for krigsforbrydelser mod Ententen, risici, der bestemt ikke kunne udelukkes ikke mindst på baggrund af det brutale tyske felttog i Belgien i efteråret $1914 .{ }^{13}$ Her havde Ludendorff grebet afgørende ind og bl.a. personligt gennemført erobringen af Liége. Herved havde han afbødet en foreløbig tysk fiasko overfor de belgiske styrker allerede i felttogets første dage. En handling, der af kejseren var blevet belønnet med den højeste preussiske orden Pour le Mérite, men som til gengæld af belgierne blev takseret som et præludium til de krigsforbrydelser, man fandt den tyske hær skyldig i.

General Ludendorff opholdt sig knap 3 måneder hos familien Olsson på Hässleholm, fra den 24. november 1918 til den 21. februar 1919. Da var forholdene blevet så stabile i Berlin, at generalen ikke længere frygtede for sit liv. Hertil kom, at den svenske regering, der allerede via pressen var blevet opmærksom på generalkvartermesteren, ikke længere ønskede at bevilge ham ophold i Sverige. ${ }^{14}$

I løbet af sit illegale ophold på det skånske gods lykkedes det Erich Ludendorff at udarbejde råmanuskriptet til sin erindringsbog om krigen, et værk, der i den trykte form blev på 628 foliosider. 
Når det kunne lade sig gøre at udarbejde et så omfattende, analytisk og detaljeret værk på så kort tid, skyldtes det flere forhold. For det første fremgår det af et brev fra Ludendorff til Breucker, at han allerede forud havde sendt en skitse af værket til generaldirektør Zimmermann fra Scherl Verlag, således at ramme og disposition af bogen formentlig forelå, før Ludendorff satte foden på svensk grund. ${ }^{15}$ Dernæst var det afgørende, at generalen på Hässleholmgård gennemgående fik ro til at arbejde; han skrev stort set fra kl. 8.00 om morgenen frem til midnatstid kun afbrudt af korte spisetider og en enkelt spadseretur i parken og i skoven omkring Hässleholmgård; samtidig fik han virksom hjælp både af Wilhelm Breucker og af Adolf Fischer, ligesom Margarethe Ludendorff fra Berlin havde medbragt forskelligt materiale til arbejdet, som generalen havde savnet. Adolf Fischer påtog sig at få Ludendorffs håndskrevne manuskript renskrevet på gesandtskabet i København ved sin sekretær. Ingenlunde nogen enkel opgave, hvis man dømmer efter den forhastede og sjuskede håndskrift, som generalen betjente sig af. Mens Fischer overvejende fungerede som korrekturlæser og redaktionssekretær, virkede Breucker som researcher for Ludendorff i Berlin, idet han måtte fremskaffe bøger, kortmateriale samt aviser med polemik for og imod generalens person og krigsførelse; forhold han mange år senere - i 1953 - skildrede i sin bog Die Tragik Ludendorffs. Dømmer man efter de kommentarer i Breuckers bog, som ledsager en række udsnit fra Ludendorffs breve til Breucker, har han tilsyneladende ikke kendt til generalens samtidige 24 breve til Adolf Fischer. I disse breve kan man i meget store træk følge kronologien i den ganske hekti- ske udarbejdelse af bogen. Ved siden af arbejdet med manuskriptet viderebefordrede Fischer også breve fra generalen til forskellige forbindelser i Tyskland, idet han lod Ludendorffs breve indgå som diplomatpost i sine egne depecher til krigsministeriet. Hverken Breuckers eller Fischers breve til Ludendorff synes at foreligge. ${ }^{16}$ Fischers viderebefordring af generalens og Breuckers korrespondance som diplomatpost skulle sikre deres brevveksling mod nyfigen aktindsigt fra Tysklands eller Ententens myndigheder. En risiko, der muligvis ikke var reel, men som spøgte hos de involverede. De breve, Ludendorff sendte Breucker, er mere fortrolige end de samtidige til Fischer, og de rummer dels politiske vurderinger af krigen og krigsnederlagets følger for Tyskland, dels udfald mod general Wilhelm Groener, der efter kejserens afskedigelse af Ludendorff den 26. oktober $1918 \mathrm{mod}$ hans ønske havde efterfulgt ham som Erster Generalquartiermeister. General Groener benævnes direkte som bagtaler, stræber og skurk. Ludendorffs breve til Wilhelm Breucker siger derfor en del om hans bitterhed og den ydmygelse, generalkvartermesteren har følt ved nederlag og afskedigelse. De breve, som Ludendorff samtidig sendte til Fischer indeholder ingen udfald, men er alene af praktisk karakter, om end han særligt i de sidste breve udtrykker en stigende utålmodighed både efter at forlade det svenske eksil og efter at afslutte krigserindringerne.

Fischer nævner i sin beretning om Ludendorffs flugt, at han flere steder rensede eller mildnede manuskriptet for angreb på Wilhelm 2. og på feltmarskal Paul von Hindenburg. I den forbindelse erindrede Fischer Ludendorff om den fornemme tavshed, som den østrig-ungarske general 
Ludwig von Benedek opretholdt efter det østrigske nederlag mod preusserne i krigen 1866, til trods for at wienerpressen med regeringens accept gjorde ham til syndebuk. - Denne opfordring til Ludendorff var Fischer ikke ene om. Sven Hedin, der en lang aften havde måttet høre generalen læse op af sit manuskript på Hässleholm, havde i et brev efterfølgende rådet ham til at udelade sine bitre angreb. Ludendorff synes at have fulgt henstillingerne fra Fischer og Hedin; i alt fald finder man kun anerkendelse of Hindenburg i den trykte udgave af Meine Kriegserinnerungen 1914-1918. ${ }^{17}$

Arbejdet med Meine Kriegserinnerungen foregik på den måde, at Fischer fik de enkelte manuskriptark tilsendt afsnit for afsnit, eller han afhentede dem personligt på Hässleholmgård, mens han så returnerede de maskinskrevne og redigerede dele af manuskriptet, han havde nået at gennemgå og få maskinskrevet. Over for Fischer var Ludendorff lutter taknemmelighed, men i de samtidige breve til Breucker, klager han nogle gange over Fischers langsommelighed, hvilket ikke forekommer rimeligt, når man tager generalens skrift i betragtning. Ved modtagelsen af Fischers renskrift blev den gennemgået og rettet til, hvorefter Ludendorff lod fremstille yderligere to maskinskrevne kopier i Sverige, idet det lykkedes ham at få den tyske militærattaché i Stockholm Eberhard von Giese til parallelt med Fischer at foretage disse maskinafskrifter. ${ }^{18}$

\section{Epilog}

Efter Ludendorffs hjemkomst til Berlin havde Adolf Fischer indtil udgangen af 1919 endnu personlig forbindelse med ham. Han introducerede således forfatteren Karl Larsen for generalen, idet de sammen besøgte ham i Berlin i december 1919. Besøget resulterede den 9. og 10 december 1919 i to kronikker af Karl Larsen i Politiken: "Ludendorff indenfor fire Vægge" og "Ludendorff ude og hjemme." Med Adolf Fischer som kilde var disse to kronikker den første, samlede offentlige beretning om Ludendorffs flugt. Karl Larsens fremstilling er dog - ikke overraskende - strammet journalistisk i forhold til Fischers beretning.

I eftersommeren 1919 udkom Ludendorffs Meine Kriegserinnerungen 1914-1918 i Tyskland. Bogen kom også på dansk, engelsk, fransk, svensk, spansk og russisk. Den blev faktisk en international bestseller. Den svenske udgave blev hjulpet stærkt på vej af Sven Hedin, der ligesom Karl Larsen havde været en slags tysk påvirkningsagent under Den store Krig. Hverken han eller Karl Larsen lagde deres tyske sympatier fra sig efter det wilhelminske riges kortlivede, 48-årige eksistens mellem 1870 og 1918. For Karl Larsens vedkommende blev der $\mathrm{i}$ årene efter Verdenskrigen snarere tale om en forbitret radikalisering, hvori der både indgik raceteori og Ludendorff-fascination. Det sidste kom bl.a. til udtryk i hele to anmeldelser af den danske oversættelse af Meine Kriegserinnerungen først i Politiken den 7. september 1919 og siden i efterårsnummeret samme år af tidsskriftet Litteraturen. ${ }^{19}$ Karl Larsen var i begge anmeldelser gået stærkt i rette med udgaven, og han endte med at karakterisere den danske oversættelse som det værk, der "indenfor den hele danske Oversættelseslitteratur havde naaet en Rekord med Hensyn til Stilløshed, Unøjagtighed og til tider ofte grotesk Fejlagtighed" ${ }^{20}$ Karl Larsen slap aldrig sin Ludendorfffascination, og så sent som i 1930, året 
før sin død, forsøgte han at etablere et samarbejde med Ludendorff, således at han skulle repræsentere generalens forfatterrettigheder i Danmark og Norge, men Ludendorff havde med beklagelse måttet afslå Karl Larsens tilbud, han havde været for sent ude, idet den faldne storhed $i$ forvejen blev repræsenteret af Aschehoug i Danmark og Norge, mens Bonnier sad på det svenske marked og faktisk også formidlede de engelske, franske, russiske, spanske og italienske udgaver af Meine Kriegserinnerungen 1914-1918.

Efter Kapp-kuppet og Ludendorffs involvering i Hitlers ølstuekup den 8.-9. november 1923 skiltes Fischers og Ludendorffs veje definitivt. Tilbage i Adolf Fischers omfattende bogsamling i Palægade i København stod der både den danske og den tyske udgave af Meine Kriegserinerungen 1914-1918. I den tyske udgave fandtes følgende formelt ydmyge dedikation: "Seinem Mentor in Dänemark, Hauptmann Fischer. Ludendorff." - Til hans mentor i Danmark, kaptajn Fischer. Ludendorff. Betegnelsen til hans mentor med brug af tredjeperson-formen, som den tidligere Erster Generalquartiermeister har benyttet her, er velsagtens både et udtryk for en tilsyneladende beskedenhed, samtidig med at der markeres en vis afstand til Fischer; men derved bliver dedikationen vel egentlig ganske hoven og kan måske ses som et varsel om den ekstreme - og bitre - selvhævdelse, som indtil Ludendorffs død i $1937 \mathrm{kom}$ til at præge hans senere forfatterskab om konspiration mellem katolikker, jøder og frimurer som selve ophavet til krigsnederlag og tysk deroute. Forestillinger, der vidtgående blev indgivet Ludendoff af hans anden hustru, lægen og psykiateren Mathilde Ludendorff.
På trods af sin utilfredshed med Fischers arbejdstempo under udarbejdelsen af krigserindringerne endte Ludendorff alligevel med i taknemmelighed at forære Adolf Fischer sit næsten ulæselige råmanuskript til Meine Kriegserinnerungen. Fischer lod siden manuskriptet indbinde og indlemmede det i sit bibliotek eller arkiv.

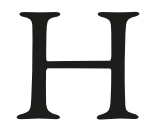
istorien om Ludendorffs flugt
og om tilblivelsen af manuskrip-
tet til hans krigserindringer fortalte Adolf Fischers søn, den navnkundige kunsthistoriker og chef for Kobberstiksamlingen på Statens Museum for Kunst, dr.phil. h.c. Erik Fischer, til Erland Kolding Nielsen og undertegnede engang i forsommeren 2000. Vi lyttede forbavsede til fremstillingen, men brød ind med et inkvisitorisk:

— "OG HVOR ER SÅ DET MANUSKRIPT NU, ERIK?”

- "Ja, min fader blev rent ud forbandet på Ludendorff, efter at han var begyndt at samarbejde med Hitler, så manuskriptet blev solgt med den klausul, at det ikke måtte sælges til Tyskland eller til en tysker, det er nu på Harvard University Library". — "Nå, sådan - ja-a, vel."

Og så sivede al luft ud af vores forventning om at kunne slå klørene i generalens manuskript.

$\mathrm{I}$ forbindelse med et andet arbejde med tilknytning til besættelsestiden gennemgik jeg sent på året 2014 nogle affotograferede indberetninger fra den tyske gesandt Cecil von Renthe-Fink på Rigsarkivet. ${ }^{21}$ Til min forbavselse stødte jeg på et telegram fra den 29. februar 1940, der noget usædvanligt var stilet til Kriegsmarine. Af telegrammet frem- 
gik det, at Renthe-Fink via en "Kapitän Westermann"22 kunne meddele, at der i København var sat et manuskript med Ludendorffs Kriegserinnerungen til salg med den klausul, at manuskriptet ikke måtte erhverves af Tyskland eller af en tysker. ${ }^{23}$ Ud fra den formulering og Erik Fischers bemærkninger om faderens holdning til Ludendorff og hans manuskript, måtte det være Adolf Fischer, der havde sat manuskriptet til salg på dette sene tidspunkt. Renthe-Fink havde ikke kunnet identificere sælgeren, men havde noteret sig klausulerne, og for at omgå de i hans øjne sikkert fornærmelige bestemmelser havde han entreret med en såkaldt dansk "Mittelsmann” om at købe manuskriptet. Det var den velmeriterede danske marineoverlæge Holger Rasmussen, der fik opgaven at erhverve manuskriptet, som var sat til den formidable pris af $25.000 \mathrm{kr}$. Det fortaber sig indtil videre i mørket, hvem “Kapitän Westermann" var, og hvordan Renthe-Fink er kommet i forbindelse med ham og den danske marineoverlæge, men en af dem eller begge kan muligvis have haft en eller anden forbindelse med Abwehr; hermed være ikke insinueret, at de pågældende har været agenter for Abwehr, om end den danske marineoverlæge må have været villig til at optræde som køber af manuskriptet på vegne af Tysklands gesandt. $^{24}$

Renthe-Fink må have fået pengene bevilget fra Berlin; i alt fald lykkedes det Holger Rasmussen at agere stråmand, eftersom Erich Ludendorffs manuskript på trods af alle Adolf Fischers klausuler alligevel blev købt af den danske ma- rineoverlæge, der straks "videresolgte" håndskriftet til det daværende Heeresarchiv i Potsdam. Denne institution blev ødelagt ved slutningen af Anden Verdenskrig, og værdifulde arkivsamlinger gik på den måde tabt for eftertiden, men Ludendorffs manuskript må på en eller anden måde være undsluppet ødelæggelsen, thi det befinder sig i dag i Bundesarchiv - Militärarchiv Freiburg under signaturen N 77 Erich Ludendorff nr.1.

Den svenske arkivar James Cavallie havde lejlighed til at se det omkring 1990, da han skrev på sin fremragende bog Ludendorff och Kapp i Sverige, og han gav en kortfattet beskrivelse af håndskriftet og det, der på den tid kunne vides om manuskriptets proveniens: "I Bundesarchiv-Militärarchiv i Freiburg förvaras en vackert inbunden volym, som innehåller ett av Ludendorff egenhändigt skrivet manuskript till krigsminnena. Manuskriptet har en brokig ägarhistoria. Troligen kort för andra världskrigets utbrott köpte Heeresarchiv i Potsdam det av en dansk marinöverläkare; hur det kommit i dennes ägo är inte känt." ${ }^{25}$ Med oplysningerne fra Adolf Fischers beretning om Ludendorffs flugt og om tilblivelsen af Meine Kriegserinnerungen, samt Cecil von Renthe-Finks indberetning fra den 29. februar 1940 er det nu kendt, hvorledes Ludendorffs råmanuskript alligevel endte i Tyskland på trods af Adolf Fischers bestræbelser på at undgå et tysk ejerskab, og hermed et der lagt de måske sidste brikker i et historisk puslespil, hvor James Cavallie fra det svenske Riksarkiv unægtelig har lagt de fleste og største. 


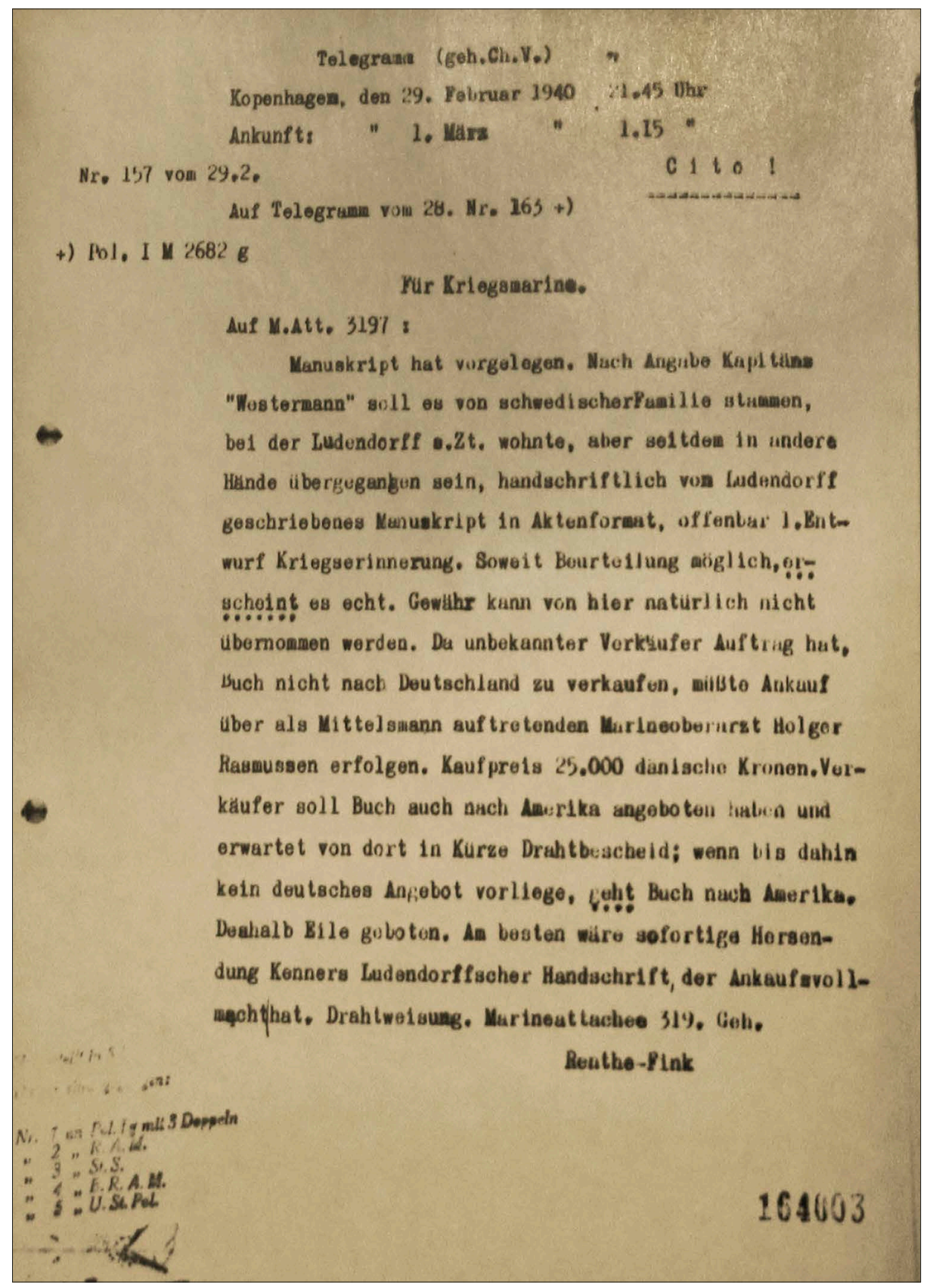

Renthe-Finks telegram fra den 29. februar 1940. Rigsarkivet.

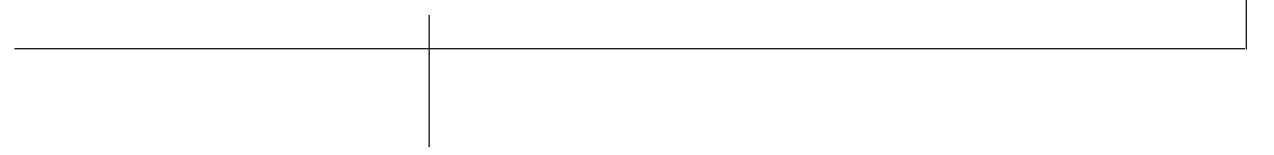




\section{Noter}

1 Artiklen bygger på Adolf Fischers levende redegørelse for Ludendorffs flugt under inddragelse af James Cavallies iagttagelser i hans fremragende bog, $\mathrm{Lu}$ dendorff och Kapp i Sverige, Stockholm 1993. Af gode grunde kunne Cavallie ikke kende noget til Adolf Fischers beretning. Undertegnede fik først kendskab til Adolf Fischers beretning i forsommeren 2000, da jeg af afdøde kunsthistoriker dr.phil. h.c. Erik Fischer, søn af Adolf Fischer, fik overladt faderens beretning om hans andel i Ludendorffs flugt samt 24 breve fra Erich Ludendorff til Adolf Fischer i forbindelse med udarbejdelsen af min bog om digteren Karl Larsen, Den smilende Kamaleon, Kbh. 2013. Efter jeg havde kopieret materialet, blev det leveret tilbage til Erik Fischer, og efter dennes død i 2012 er det indgået i Det Kongelige Bibliotek.

2 I forholdet mellem Fischers beskrivelse af forberedelserne til flugten og de 4 fremstillinger, som Breucker siden gav heraf, af hvilke de tre tidligste fremkom på Ludendorffs opfordring, er der forskellige afvigelser. Om Breuckers og de to finske diplomaters fremstillinger se James Cavallies grundige redegørelse i: Ludendorff och Kapp i Sverige, Stockholm 1993, s.17ff. Fischers fremstilling har Cavallie af gode grunde ikke kunnet kende.

3 Wilhelm Breucker: Die Tragik Ludendorfs, (Stollhamm 8 Oldenb.) [1953] s. 78.

4 Breucker nævner, at der udstedtes mere end et pas til Ludendorff i det finske gesandtskab, idet han omtaler dem som Passformulare og Pässe, men han nævner til gengæld kun navnet Erik Lindström. Breucker s. 78. Cavallie har også lagt mærke til forholdet vedr. passpørgsmålet og reflekteret over det. Se Cavallie s. 21.

5 Cavalie redegør for hele den finske indblanding s. $19 \mathrm{ff}$.
6 Ordskiftet findes i Fischers beretning, den er her oversat fra tysk af undertegnede. I et brev til hustruen, som Ludendorff skrev på Hotel Phønix, nævner han episoden med ubehag, og han nævner West ved navn. D.v.s. West og Ludendorff må egentlig have genkendt hinanden. Se Margarethe Ludendorff: Als ich Ludendorffs Frau war, München 1929, s. 213.

7 General Ludendorff: Vom Feldherrn zum Weltrevolutionär und Wegbereiter deutscher Volksschöpfung Meine Lebenserinnrungen von 1919 bis 1925, Ludendorff Verlag, München 1940, s. 34. Om Brockdorffs udfordring af Ludendorff til duel se Edgar Stern-Rubarth: Graf Brockdorff-Rantzau Wanderer zwischen zwei Welten. 2. udg. Berlin 1968, s. 100. Ludendorff undslog sig for at tage imod udfordringen med den begrundelse, at Brockdorff forud havde ytret sig offentligt om sagen. BrockdorffRantzau udsendte derpå en for Ludendorff tilintetgørende erklæring via Theodor Wolffs telegrambureau.

8 Cavallie, s. 28.

9 General Ludendorff: Vom Feldherrn zum Weltrevolutionär und Wegbereiter deutscher Volksschöpfung Meine Lebenserinnerungen von 1919 bis 1925, Ludendorff Verlag, München 1940, s. 34.

10 Adolf Fischers Menschen und Tiere... bragte ham i forbindelse med datidens største tyske antropolog, Leo Frobenius (1873-1938), der indbød Fischer til at blive korresponderende medlem af Forschungsinstitut für Kulturmorphologie an der Johan Wolfgang Goethe-Universität Frankfurt a. M.

11 Adolf Fischer: Orient, Berlin-Leipzig 1924. Adolf Fischer: Südwester Offiziere, Berlin [1935] og Adolf Fischer m.fl.: Afrika spricht zu Dir: Selbsterlebnisse deutscher Kolonialpioniere, Mühlhausen/Thüringen 1938.

12 Margarethe Ludendorff s. 213. 
13 Med udarbejdelsen af sine Kriegserinnerungen var Ludendorff ganske forudseende, idet han i sommeren og efteråret 1919 måtte stille for et undersøgelsesudvalg, som den tyske nationalforsamling havde udpeget. Udvalget sluttede sit arbejde i foråret 1920 uden at kunne stille Ludendorff til regnskab.

14 Udførligt beskrevet af Cavallie, se s. $38 \mathrm{ff}$.

15 Breucker s. 165. Bogen kom dog ikke på Scherl Verlag, men hos Ernst Siegfried Mittler und Sohn i eftersommeren 1919.

16 Cavallie nævner s. 35, at han forgæves har søgt efter Ludendorffs breve til Breucker, der kendes kun de udsnit, som Breucker publicerede i sin bog Die Tragik Ludendorffs i 1953. En hæmsko har været, at Cavallie lige så lidt som andre forskere har kunnet få adgang til Ludendorffs papirer, der er i privat eje i Tutzing i Bayeren. Ludendorffs breve til Fischer har Cavallie af gode grunde ikke kunnet kende.

17 Hedins brev er citeret af Cavallie, s. $78 \mathrm{ff}$.

18 Breucker s. 168ff.

19 Indtil 11. november 1918 havde Litteraturen været subventioneret af det tyske gesandtskab i København, som en del af Louis von Kohls tidsskrift- og propagandaimperium. I efteråret 1918 var Kohls imperium dog gået lige så hastigt til grunde som det knap halvtredsårige tyske kejserrige, men selv på så fremrykket et tidspunkt som december 1918 havde det tyske gesandtskab måttet stampe 100.000 kr. op til dækning af de kohlske foretagender for at undgå skandale.

20 Se Litteraturen 1919-20, s. 408.
21 Fotografier fra Auswärtiges Amt, SSKontorer. Rigsarkivet.

22 Der er næppe tale om nogen tysk søofficer, men den Kapitän Westermann, som Renthe-Fink refererer til i citationstegn, er måske identisk med den danske kommandørkaptajn Carl August Severin Westermann (1894-1947). Havde der været tale om en tysk søofficer fra Kriegsmarine, ville den korrekte og formelle Renthe-Fink efter al sandsynlighed have omtalt ham med hans præcise titel: Korvettenkapitän eller Fregattenkapitän. Kommandørkaptajn Westermann havde den 29. august 1943 kommandoen på artilleriskibet Niels Juel. Han valgte at sætte skibet på grund ud for Anneberg i Isefjorden og ødelægge det efter et forgæves forsøg på at bringe skibet til Sverige.

23 Rigsarkivet. AA. Pk. 200, dokument 164003.

24 Det er gxtteri fra min side, som dog bygger på tre iagttagelser: At Renthe-Finks telegram er stilet til Kriegsmarine og ikke direkte til Ausw. Amt. At salget af Ludendorffs manuskript tilsyneladende er blevet opsnappet af en Kapitän Westermann, samt det forhold at Admiral Canaris' Abwehr i ganske stor udstrækning benyttede sig af flådeofficerer og deres netværk, idet skibstrafikken i de danske stræder havde stor interesse for Tyskland, men andre muligheder kan sagtens tænkes.

25 Cavallie, s.81ff. Cavallie nævner, at manuskriptet omfatter 234 sider folio beskrevet på begge sider foruden et antal tillægslapper. 